\title{
CHARACTERIZATION OF THE WOOD PROPERTIES OF Cedrelinga cateniformis AS SUBSTITUTE FOR TIMBERS USED FOR WINDOW MANUFACTURING AND OUTDOOR APPLICATIONS
}

\author{
Volker Haag $^{1 \star}$, Gerald Koch ${ }^{1}$,Eckhard Melcher ${ }^{1}$, Johannes Welling ${ }^{1}$
}

\begin{abstract}
Cedrelinga cateniformis (tornillo) is a timber species of the South American Amazon Basin. In its natural distribution area, the wood has various local uses, such as furniture, art work, door and window frames, and light construction. In order to promote this lesser known species for high valued applications on the international market, wood anatomical, topochemical and physical/mechanical studies were carried out to characterize the wood properties. The topochemical distribution of the lignin and phenolic extractives in the tissue were studied by means of cellular UV microspectrophotometry (UMSP). The results of the structural and topochemical analyses were compared with the interrelation of certain anatomical and subcellular structures as well as the chemical composition with regard to the physical and mechanical properties. The natural durability of the mature heartwood was analyzed according to the European Standards and is resulting in a durability class 1 against basidiomycetes. Based on the findings of the comprehensive investigations concerning physical and biological features, e.g. the dimensional stability and durability, Cedrelinga cateniformis is ideally suited as a substitute for overexploited tropical woods currently used in Europe for wooden window frames and other above ground outdoor applications and thus can contribute to increase the value-added production in Peruvian forests.
\end{abstract}

Keywords: Biological durability, cellular UV microspectrophotometry, dimension stability, lesser known species, topochemistry, wood anatomy, wood extractives.

\section{INTRODUCTION}

Particular advantages of certain tropical woods compared to woods from temperate origins are suitable properties, especially in terms of natural durability, dimensional stability and high strengths. In Europe, therefore, tropical woods are highly requested for applications like terrace decking, window scantlings or door construction. Consequently, during the past years the demand for timber with a high natural durability has increased significantly while the supply of traditionally traded timbers from natural tropical forests is getting more and more difficult (Brown et al. 2003, Verwer et al. 2008, Putzel et al. 2011). In this context, plantation-grown timbers are favored as a considerable potential for ensuring a sustainable wood production and for reducing the pressure on timber from natural forests. However, the material obtained from these plantations is "different" in its wood quality when compared with wood provided from natural forests (Haupt et al. 2003). The differences basically depend on the anatomical structure and chemical composition. For example, narrow and wider annual rings, different proportions of early-wood and late-wood, higher percentage of juvenile wood and different amounts of extractives might affect the properties such as density, swelling, shrinkage, strength and hardness as well as natural durability as the criterion qualifying a species for outdoor use.

\footnotetext{
${ }^{1}$ Thünen Institute of Wood Research, Hamburg, Germany.
}

•Corresponding author: volker.haag@thuenen.de

Received: 16.06.2019 Accepted: 04.10.2019 
The most commonly tropical timber used (or requested) in the European market come from the family of Meliaceae (mahogany family) as wood of the genera Entandrophragma spp. (Hall 2008, Hall 2011) and Swietenia spp. (Gullison et al. 1992, Gullison et al. 1996), and wood from the Dipterocarpaceae family, most notably wood of the genus Shorea subg. Rubroshorea spp. known under the trade name Meranti (Koch 2016, Purwaningsih and Kintanmani 2018) and subg. Shorea representing the assortment of Yellow balau, bangkirai. A recurrent problem in the history of the tropical timber industry is the over exploitation (Sist et al. 1998, Sist and Nguyen-Thé 2002, Sist et al. 2003, Grogan et al. 2008, Günter et al. 2011, Inada et al. 2017) and illegal logging (Grossheim 2011) of certain trade assortments such as mahogany or meranti, while other tree species, so-called "lesser known species" with comparable technical properties and sufficient forest availability remain underutilized (Foerster et al. 2003, Silva-Guzmán 2012).

In context of the project "Developing Competences in the Peruvian Forestry and Woodworking Sector", several so called lesser known species from Peruvian forests were examined with a view to marketing options in Europe. After extensive research in cooperation with the state research institutes CITEmadera and CITEforestal as well as regional timber merchants, it was decided to investigate to what extent the wood species $\mathrm{Ce}$ drelinga Cateniformis is suitable to substitute established wood species for window construction and outdoor use in Europe.

Its natural distribution extends across the entire Amazon basin from eastern Peru to the lower reaches of the Amazon in the Brazilian state of Para. Due to the positive growth characteristics and wide spread of the wood species there is sufficient stock in the Peruvian Amazon region to ensure a longer-term supply for the markets. Harvesting concessions are mostly certified and sustainably managed. Sawn timber in various dimensions, semi-finished and finished goods with FSC certificate are available. Regarding its positive mechanical and technical characteristics (Barefoot and Traywick 1971) it is very versatile and especially in Peru of great wood economic importance. However, Cedrelinga cateniformis is yet an unknown timber assortment in Europe.

The aim of the present study is to provide detailed information on the wood properties of Cedrelinga cateniformis. It combines comprehensively the results using a variety of state-of-the-art methods in view of the current requirements of the wood as substitute for established timbers used for window manufacturing and outdoor applications in Europe.

\section{MATERIALS AND METHODS}

\section{Materials}

The examined timber samples are originated from a FSC certificated concession in a natural forest in the districts of Iberia and Tahuamanu, Province of Tahuamanu, Department of Madre de Dios, Peru. Cedrelinga cateniformis (Ducke) Ducke is a monotypic species. Due to its very individual wood structure it is possible to exclude any confusion with other timbers on standard wood anatomical investigations. In total, samples from 40 different boards $(70 \mathrm{~cm} \times 9 \mathrm{~cm} \times 3,5 \mathrm{~cm})$ from 3 different trees were examined. There is no precise information about the age of the trees tested as they originated from natural forests. Based on the results of the structural analysis regarding the potential growth rate of the species ( $2 \mathrm{~mm}$ to $5 \mathrm{~mm}$ per year) of the natural forest trees, all trees investigated where considered older than 50 years. Further, 2 samples of the scientific wood collection of the Thuenen Institute of Wood Research with origin of Brazil where investigated with view on the natural variation of the wood structure.

\section{METHODS}

\section{Light microscopy}

Transverse, radial and tangential sections (around $20 \mu \mathrm{m}$ thick) of air-dried specimens were cut sequentially from the specimens with a sliding microtome (Sartorius sliding microtome) Transverse, radial and tan- 
gential sections (around $20 \mu \mathrm{m}$ thick) of air-dried specimens were cut sequentially from the specimens with a sliding microtome (Sartorius sliding microtome) and embedded in Euperal (Roth Art.-Nr. 7356.1). Dry wood specimens were embedded in Spurr's epoxy resin (Spurr 1969) under mild vacuum with several cycles of evacuation and ventilation according to Kleist and Schmitt (1999) followed by polymerization over night at a temperature of $70{ }^{\circ} \mathrm{C}$. Transverse sections $(1 \mu \mathrm{m}$ thick) were prepared from epoxy resin embedded specimens with an ultracut microtome (Ultracut E, Reichert \& Jung). The sections were stained with a $1 \%$ aqueous toluidine blue solution for studying microstructural details (pits, cell wall areas, etc.). Tissue macerations were prepared for measurement of vessel-ray pit size, fiber length and vessel element length. Maceration followed the procedure of Franklin (1945) for which small wood blocks $(1 \mathrm{~cm} \times 1 \mathrm{~cm} \times 1 \mathrm{~cm})$ are split into $1 \mathrm{~mm}$ thick slivers and placed in test tubes containing a 1:1 mixture of a 30 percent hydrogen peroxide solution and acetic acid. After about 2-4 days (depending on wood density), individual cells were obtained for subsequent measurements. Vessel element and fiber morphology were determined according to Helmling et al. (2018).

Wood anatomical studies focused on heartwood since sapwood has different properties (e.g., natural durability) and is of hardly any economic relevance. Terminology and description of wood structure are based on the IAWA List of microscopic features for hardwood identification (Wheeler et al. 1989). In certain cases, quantitative categories (e g, "fiber wall thickness: thin, thin to thick, very thick") were substituted by numerical values. Furthermore, data not specified in the IAWA List were collected (e g, tangential diameter of fiber lumina). A digitized image analysis system (analySIS ${ }^{\circledR}$, Olympus) mounted on an Olympus AX 70 microscope was used for quantitative features based on an average of at least 50 (by default 100) measurements of each parameter studied (Hapla and Saborowski 1987).

Overall, 25 anatomical features considered important for the anatomical description (anatomical "fingerprint") were selected as they are supposed to have a considerable influence on the physical and mechanical properties of the wood.

\section{Field emission scanning electron microscopy (FESEM)}

For analyzing micro structural details (e.g., vessel pit apertures, pit canals etc.), a FEI Quanta 200 FESEM was used. Prior to examination, the samples were brought to a final size of about $10 \mathrm{~mm}$ x $10 \mathrm{~mm}$ x $2 \mathrm{~mm}$ with subsequent careful smoothening of their surfaces with razor blades, then mounted onto aluminum stubs with carbon paste, and finally sputter-coated with gold. Accelerating voltage during examination varied between 5 $\mathrm{kV}$ and $10 \mathrm{kV}$.

\section{Cellular UV-microspectrophotometry}

Specimens from the heartwood of Cedrelinga cateniformis were trimmed with chisel and razor blades to a final size of about $3 \mathrm{~mm}$ x $3 \mathrm{~mm}$ x 9mm, which were directly embedded in Spurr's epoxy resin (Spurr 1969). Briefly, the dry wood specimens became infiltrated with Spurr's epoxy resin under mild vacuum with several cycles of evacuation and ventilation according to Kleist and Schmitt (1999) followed by polymerization over night at a temperature of $70{ }^{\circ} \mathrm{C}$.

The subcellular distribution of lignin and phenolic extractives was investigated using Scanning UV microspectrophotometry following Koch and Kleist (2001) and Koch and Grünwald (2004). Spurr embedded specimens from the different tissues (juvenile and adult heartwood) were selected from which transverse sections of $1 \mu \mathrm{m}$ thickness were cut using an ultra-microtome equipped with a diamond knife. These sections were transferred to quartz microscope slides, thermally fixed on a heating plate, immersed in a drop of non-absorbing glycerol (glycerol/water mixture) and covered with a quartz cover slip. The analyses were carried out using a Zeiss UMSP 80 micro-spectrophotometer equipped with a scanning stage which enables the elaboration of image profiles at defined wavelengths with the scan software APAMOS ${ }^{\circledR}$ (Zeiss). For detection of lignin and phenolic extractives a wavelength of $278 \mathrm{~nm}$ (absorbance maximum of hardwood lignin) was selected. This scan program digitizes rectangular fields in the tissue with a local geometrical resolution of $0,25 \mu \mathrm{m} \times 0,25 \mu \mathrm{m}$ and a photometrical resolution of 4096 grey scale levels which are converted into 14 basic colors to visualize the absorbance intensities. 


\section{Durability tests against basidiomycetes}

The durability tests were performed according to EN 350-1(1994) and CEN/TS 15083-1(2005) using the following obligatory strains:

- Coniophora puteana (Schumacher ex Fries), BAM Ebw. 15 for hardwoods and softwoods

- $\quad$ Trametes (Coriolus) versicolor (Linnaeus) Quélet, CTB 863A for hardwoods

Additional test fungi:

- Gloeophyllum trabeum (Persoon ex Fries), BAM Ebw. for softwoods

- Serpula lacrymans (Schumacher ex Fries), BAM 315 for softwoods

After gamma sterilization test specimens with a dimension of $50 \mathrm{~mm}$ x $25 \mathrm{~mm}$ x $15 \mathrm{~mm}$ were placed onto stainless steel rings in incubation jars, filled with $5 \%$ malt agar nutrient solution to a height of approx. $5 \mathrm{~mm}$. Reference specimens were prepared from Fagus sylvatica L. (European beech) and Pinus sylvestris L. (Scots pine) sapwood. Oven dry mass $\left(\mathrm{m}_{0}\right)$ was determined using separate specimens not subjected to the fungal tests.

After exposure times of 16 weeks in a climate chamber at $20{ }^{\circ} \mathrm{C}$ and $75 \%$ relative humidity all specimens were weighed $\left(\mathrm{m}_{\mathrm{me}}\right)$ to the nearest $0,001 \mathrm{~g}$ following the removal of the mycelia. The test specimens were oven-dried at $103{ }^{\circ} \mathrm{C}$ till constant mass and were weighed again $\left(\mathrm{m}_{\mathrm{dme}}\right)$. Mass loss (ML, Equation 1) due to fungal decay as well as wood moisture content after exposure $\left(\mathrm{u}_{\mathrm{e}}\right.$, Equation 2$)$ was calculated based on oven dry masses determined before $\left(\mathrm{m}_{0}\right)$ and after $\left(\mathrm{m}_{\mathrm{dme}}\right)$ fungal testing according to Equation 1 and Equation 2.

$$
M L=\frac{m_{0}-m_{d m e}}{m_{0}} \times 100
$$

ML - mass loss of specimens after exposure (\%)

$\mathbf{m}_{0}$ - oven dry mass before fungal exposure $(\mathrm{g})$

$\mathbf{m}_{\mathrm{dme}}$ - oven dry mass after fungal exposure $(\mathrm{g})$

$$
u_{e}=\frac{m_{m e}-m_{0}}{m_{0}} \times 100
$$

$\mathbf{u}_{\mathbf{e}}$ - moisture content of specimen after exposure (\%)

$\mathbf{m}_{\mathbf{m e}}$ - wet mass of specimen after fungal exposure (g)

$\mathbf{m}_{\mathbf{0}}$ - oven dry mass before fungal exposure $(\mathrm{g})$

The durability class was derived from the median mass loss according to CEN/TS 15083-1(2005) and from the "x-value" (EN 350-1(1994)) calculated on the basis of the mean mass loss using Equation 3.

$$
x=\frac{M L_{\text {tornillo }}}{M L_{\text {reference }}}
$$

$\mathbf{M L}_{\text {tornillo }}$ - mean mass loss of Tornillo after fungal test (\%) 
$\mathbf{M L}_{\text {reference }}$ - mean mass loss of the reference timber (\%)

The classification schemes of both European standards are shown in Table 1.

Table 1: Durability class (DC) according to EN 350-1(1994) and CEN/TS 15083-1(2005).

\begin{tabular}{|c|c|c|c|}
\hline DC & Description & x-value $^{\mathbf{1}}$ & Median mass loss (MML, $\mathbf{~ o ) ~}^{\mathbf{2}}$ \\
\hline $\mathbf{1}$ & Very durable & $\mathrm{x} \leq 0,15$ & $\mathrm{MML} \leq 5$ \\
\hline $\mathbf{2}$ & Durable & $>0,15 \mathrm{x}<0,30$ & $5<\mathrm{MML} \leq 10$ \\
\hline $\mathbf{3}$ & Moderate durable & $>0,30 \mathrm{x} \leq 0,60$ & $10<\mathrm{MML} \leq 15$ \\
\hline $\mathbf{4}$ & Less durable & $>0,60 \mathrm{x} \leq 0,90$ & $15<\mathrm{MML} \leq 30$ \\
\hline $\mathbf{5}$ & Non-durable & $\mathrm{x}>0,90$ & $30<\mathrm{MML}$ \\
\hline
\end{tabular}

${ }^{1}$ EN 350-1(1994), ${ }^{2}$ CEN/TS 15083-1(2005).

\section{Assessment of physical properties}

For characterizing a wood species physical properties are crucial elements. Most important features for judging potential applications are density and shrinkage/swelling behaviour.

In case of wood, density $\rho\left(\mathrm{kg} / \mathrm{m}^{3}\right)$ is defined as mass/volume at a given humidity. According to DIN 52182/1976, which is equivalent to ISO 13061-2 (2014), the volume of a specimen is determined by means of a caliper, while mass is determined gravimetrically using a high precision balance. Values for density should always be accompanied by an index indicting the humidity of the tested samples, e.g. $\rho_{0}$ for oven-dry density, $\rho_{12}$ for density at $12 \%\left(\approx \mathrm{EMC}\right.$ at $20{ }^{\circ} \mathrm{C}$ and $\left.65 \% \mathrm{rh}\right)$ or $\rho_{\text {sat }}$ (density in saturated condition).

In this investigation density was determined on small clear specimen prepared for various other physical and mechanical properties tests after conditioning at $20{ }^{\circ} \mathrm{C}$ and $65 \% \mathrm{rh}$. All specimens were oriented in such a way that growth ring direction was parallel to two opposing sides of the specimen. Such orientation allows determination of physical and mechanical properties which depend on growth ring orientation (longitudinal, radial and tangential) and minimizes deformation of the specimen when the moisture content changes during conditioning.

\section{Shrinkage and swelling properties}

DIN 52184/1979 which in most aspects is equivalent to ISO/FDIS 13061-13(2014) defines several features describing the shrinkage and swelling behaviour of small clear specimen. Shrinkage $\beta(\%)$ is defined as shrinkage from fully saturated condition to normal climate condition, differential swelling $\mathrm{q}(\% / \%)$ describes the swelling/shrinkage behaviour starting at an EMC $20{ }^{\circ} \mathrm{C} / 35 \%$ rh (dry climate) and ending at an EMC 20 ${ }^{\circ} \mathrm{C} / 85 \%$ rh (humid climate) and vice versa, expressed in percent swelling per percent moisture content change, and the swelling coefficient $\mathrm{h}(\% / \%)$ expresses the same dimensional behaviour expressed in percent per percent rh change.

In order to minimize time for the conditioning steps the dimensions of the specimens for tangential and radial were $20 \mathrm{~mm} \times 20 \mathrm{~mm} \times 10 \mathrm{~mm}$, while the specimen dimensions for the dimensional change in longitudinal direction were $20 \mathrm{~mm} \times 20 \mathrm{~mm} \times 100 \mathrm{~mm}$. The three characteristic values were determined for the tangential, 
radial and longitudinal direction, indicated by the indexes tan, rad and long, when the specimens had reached constant weight after being exposed to a new climate. Values for differential swelling q and differential swelling $\mathrm{q}$ are mean values generated from the shrinkage and the swelling pathway.

The sample collection derived from four different contingents, three known sources (three individual trees) and one unknown source (mixture of various trees or one individual tree), each comprising five boards. From each of the 5 boards 4 probes $20 \mathrm{~mm}$ x $20 \mathrm{~mm}$ x $10 \mathrm{~mm}$ and 2 probes $20 \mathrm{~mm}$ × $20 \mathrm{~mm}$ x $100 \mathrm{~mm}$ were produced.

The experimental plan showing the climate steps is visualized in Figure 1.

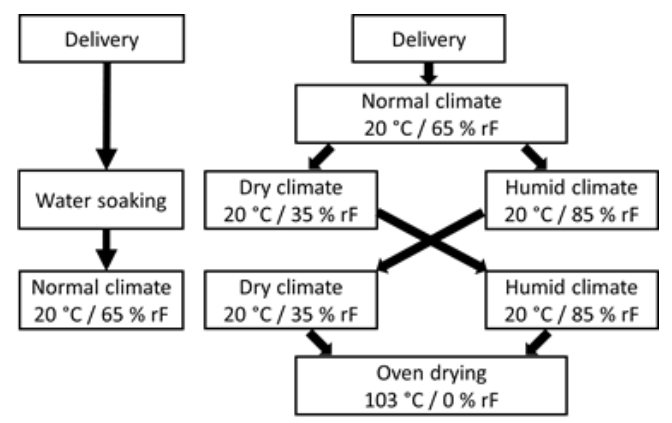

Figure 1: Experimental plan showing the climate steps.

\section{RESULTS AND DISCUSSION}

\section{Microscopic structures and wood characteristics}

The species Cedrelinga cateniformis is monotypic species and can safely be differentiated from other species on the basis of certain anatomical features.

The heartwood color varies from light to medium pinkish brown; transition to the somewhat lighter sapwood is gradual. Dry wood has no characteristic odor (though green lumber can have an unpleasant scent). The fiber orientation grain is straight to interlocked, texture uniform and very coarse, with vessel lines featuring prominently on longitudinal surfaces. The wood of Cedrelinga cateniformis is diffuse porous and the pores are very large and few. The vessels are arranged in no specific pattern or in isolated groups of 4 or more cells (Figure 2A). Pits are vestured (Figure 2E). Growth rings boundaries are indistinct and can only be recognized by thin lines of smaller latewood fibers (Figure 2B). Axial parenchyma is vasicentric or aliform. A very characteristic structural feature of the species are the chambered axial parenchyma cells/strands without any contents (Figure 2C and Figure 2D). The uniseriated and multiseriated rays are very narrow and closely spaced, in some specimens irregularly storied. Crystals where not observed in any specimens investigated. 


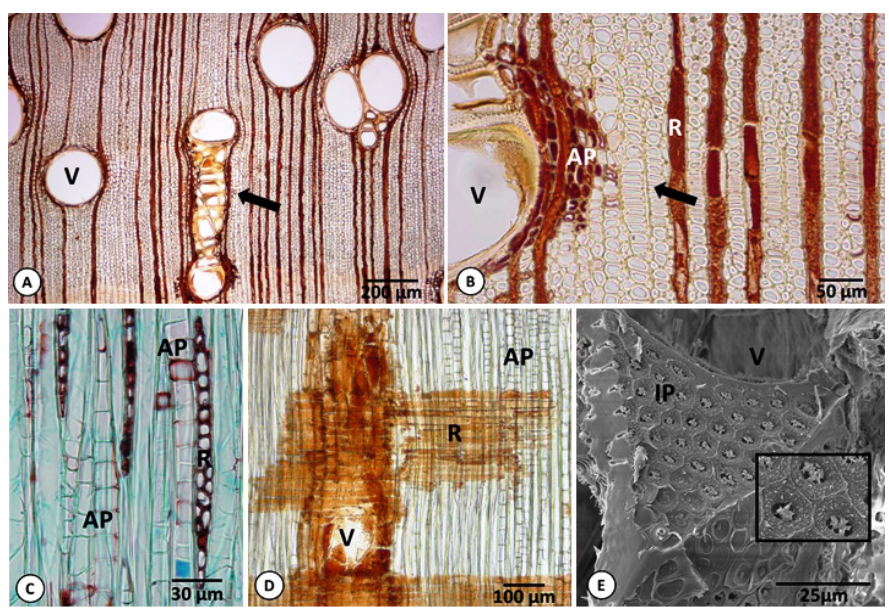

Figure 2: Cedrelinga cateniformis: (a). Transverse section with radial chains of 4 or more vessels (arrow). (b). Transverse section with vessels (V), aliform axial parenchyma (AP) and rays (R) filled with dark coloured phenolic deposits. The arrow marks thin lines of narrow latewood fibers in "indistinct" growth ring. (c). Tangential sections (stained with safranin red and astra blue) with uniseriate and multiseriate homocellular rays (R) and diffuse axial parenchyma with chambered cells/strands (AP). (d). Radial section with vessel (V), ray parenchyma (R) and diffuse axial parenchyma with chambered cells/strands (AP). (e). FESEM image showing vessel wall with vestured intervessel pits (IP). Black Box showing vestured Pits (area of interest shown by arrow) with higher magnification.

Further results of the anatomical investigation are described in Table 2.

Table 2: Results of the anatomical investigation of 3 trees originated from Peru and 2 trees originated from Brazil.

\begin{tabular}{|c|c|c|c|c|c|}
\hline Structural Features & $\begin{array}{c}\text { Tree } 1 \\
\text { Peru }\end{array}$ & $\begin{array}{c}\text { Tree } 2 \\
\text { Peru }\end{array}$ & $\begin{array}{c}\text { Tree } 3 \\
\text { Peru }\end{array}$ & $\begin{array}{l}\text { Tree } 1 \\
\text { Brazil } \\
\end{array}$ & $\begin{array}{l}\text { Tree 2 } \\
\text { Brazil }\end{array}$ \\
\hline \multicolumn{6}{|l|}{ Vessels: } \\
\hline $\begin{array}{l}\text { Tangential vessel } \\
\text { diameter }(\mu \mathrm{m})\end{array}$ & $208-376-484$ & $184-325-405$ & $146-351-472$ & $273-361-532$ & $239-362-459$ \\
\hline Number of vessels $/ \mathrm{mm}^{2}$ & $1-3(5)$ & $1-3(4)$ & $1-2(3)$ & $1-2(3)$ & $1-3(4)$ \\
\hline $\begin{array}{l}\text { Vessel element length } \\
(\mu \mathrm{m})\end{array}$ & $197-497-700$ & $200-383-583$ & $204-386-584$ & $243-509-721$ & $209-463-752$ \\
\hline $\begin{array}{l}\text { Diameter of vessel pits } \\
(\mu \mathrm{m})\end{array}$ & $6,3-7,9-9,8$ & $6,6-8,2-9,8$ & $6,1-7,6-9,8$ & $6,6-8,1-10,0$ & $6,1-7,8-9,8$ \\
\hline Vessel-ray pittings & APS* & APS* & APS* & APS* & APS* \\
\hline Pits vestured & + & + & + & + & + \\
\hline Tyloses & - & - & - & - & - \\
\hline \multicolumn{6}{|l|}{ Fibers: } \\
\hline Tangential diameter $(\mu \mathrm{m})$ & $7,7-16,5-26,2$ & $8,4-17,5-25,8$ & $7,5-15,5-27,8$ & $7,0-15,8-30,6$ & $9,6-19,1-32,0$ \\
\hline $\begin{array}{l}\text { Radial lumen diameter } \\
(\mu \mathrm{m})\end{array}$ & $3,0-10,6-19,6$ & $2,5-9,9-22,4$ & $2,7-8,9-27,1$ & $2,7-9,8-17,7$ & $2,7-9,6-20,0$ \\
\hline Cell wall thickness $(\mu \mathrm{m})$ & $1,9-3,1-5,2$ & $1,4-3,2-4,6$ & $0,9-3,2-5,2$ & $1,4-3,2-5,2$ & $1,9-3,1-4,5$ \\
\hline Fiber length $(\mu \mathrm{m})$ & $1024-1520-1905$ & $1049-1379-1838$ & $980-1460-1804$ & $947-1408-1945$ & $1081-1451-1797$ \\
\hline \multicolumn{6}{|l|}{ Axial parenchyma: } \\
\hline Banded & - & - & - & - & - \\
\hline $\begin{array}{l}\text { Average number of cells } \\
\text { per strand }\end{array}$ & $2-3(-9)$ & $3-(5-7)$ & $3-5(-7)$ & $3-5(-7)$ & $(2-) 3-5(-7)$ \\
\hline \multicolumn{6}{|l|}{ Rays: } \\
\hline$\%$ of uniseriate rays & $70 \%$ & $50 \%$ & $40 \%$ & $70 \%$ & $70 \%$ \\
\hline$\%$ of multiseriate rays & $30 \%$ & $50 \%$ & $60 \%$ & $30 \%$ & $30 \%$ \\
\hline Height of rays $(\mu \mathrm{m})$ & $111-272-466$ & $144-246-414$ & $113-221-300$ & $200-284-400$ & $140-240-330$ \\
\hline Width of rays $(\mu \mathrm{m})$ & $9,1-17,0-34,7$ & $7,5-17,0-29,5$ & $8,4-19,4-33,7$ & $11-19,2-33,7$ & $9,1-18,0-31,0$ \\
\hline
\end{tabular}

To compare the anatomical structure of wood from other regions, wood of Cedrelinga cateniformis from Brazil was examined and the results compared with those of the species from Peru. In summary, no differences can be determined on the anatomical level. The observed variation of the wood structure of five different individuals from different origins shows the natural variation of typical trading assortments from different individual location factors (nutrients, water, position of the tree in the forest, light etc.). 


\section{Cellular UV-microspectrophotometry}

The topochemical distribution and semi-quantitative determination of lignin and phenolic extractives in the heartwood tissue of Cedrelinga cateniformis were analyzed by using scanning UV microspectro-photometry. The applicability of this technique to study the lignification and natural durability of wooden tissues was demonstrated by several authors (e.g. Koch et al. 2006, Scholz et al. 2007, Dünisch et al. 2010, Blohm et al. 2014, Rodríguez et al. 2019).

(a)
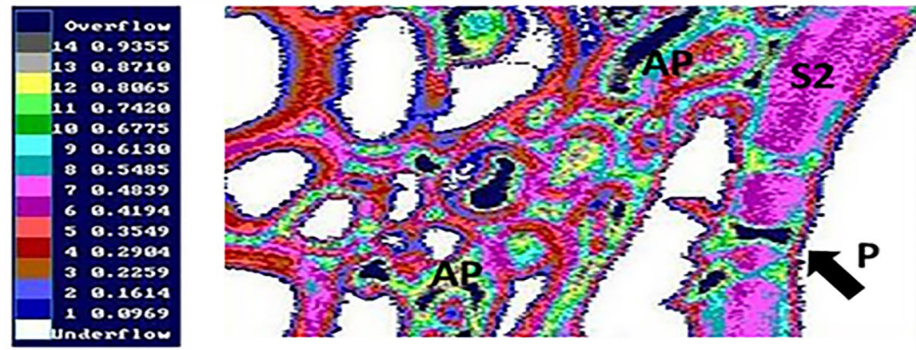

(b)
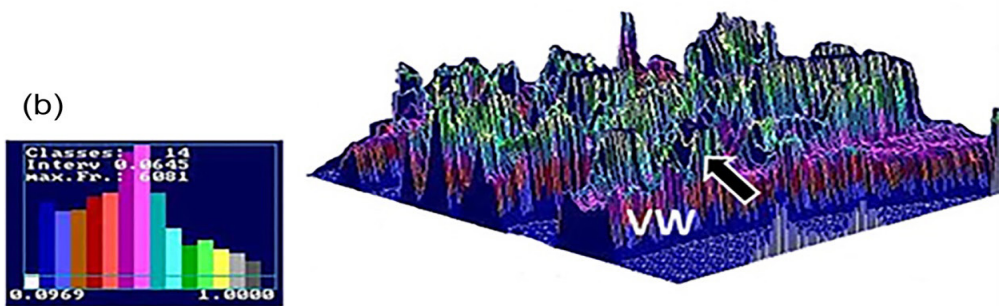

(c)
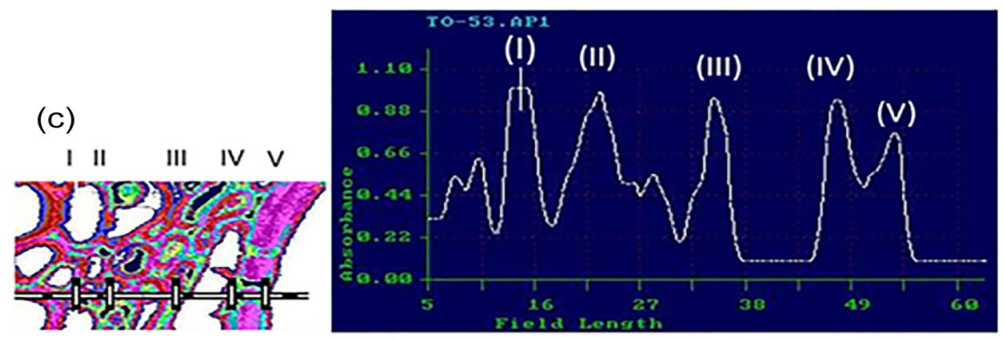

Figure 3: (a) Representative UV microscopic scanning profile of individual cell wall layers of axial parenchyma cells (AP), vessel element (S2), and impregnated pit membrane (arrow) of Cedrelinga cateniformis; (b) 3D-UV microscopic scanning profile of the selected tissue with marked pit canal (arrow) and vessel wall (VW); (c) Line scan profile across fiber tissue, axial parenchyma (I, II and III), and vessel wall with impregnated pit membrane (IV, V). The colour pixels represent different UV absorbance values measured at $\lambda 278$ $\mathrm{nm}$ (geometric resolution of $0,25 \mu \mathrm{m} \times 0,25 \mu \mathrm{m}$ ).

Figure 3 shows representative UV scanning profiles of heartwood tissue of Cedrelinga cateniformis at a defined wavelength of $278 \mathrm{~nm}$ (absorbance maximum of hardwood lignin). The individual colour pixels indicate different intensities of UV absorbance within the different tissues (fibers, axial parenchyma, vessels) and individual cell wall layers (S2, Compound middle lamella, CML and Cell corner, CC). Secondary walls (S2) of fibers, axial parenchyma and the vessel reveal a non-uniform UV absorbance in the range of 0,20 to 0,65 with highest absorbance intensities in the $\mathrm{S} 2$ of the vessel wall (represented by the violet pixels) Compound middle lamella (CML) are characterized by UV absorbance in the range of 0,45 - 0,65 illustrated by the light red and violet colour pixels, whereas in cell corners even absorbance above 0,75 to 0,90 are detectable (represented by the green any yellow pixels). The different absorbance values correlate strongly with various lignin contents and types in the individual cell wall layers e.g., the highly absorbing guaiacyl units in the S2 of the vessel wall (Koch and Kleist 2001, Koch and Grünwald 2004).

The deposition of phenolic extractives which are responsible for the natural durability of the heartwood tissue of Cedrelinga cateniformis is also clearly evident by applying the UV scanning technique. The extractives 
are detectable as local spots of high UV absorbance values (range 0,75 (yellow) - 0,80 (grey) - overflow (black)) mainly deposited in cell lumen of the axial parenchyma and locally impregnated into the cell walls of the associated fibers and vessel (Figure 3A, Figure 3B). The synthesis of the extractives and impregnation into the cell walls is initiated by low molecular phenolic precursors passing through pit membranes with subsequent conversion into highly condensed compounds during heartwood formation of Cedrelinga cateniformis.

For a more detailed verification, a special UV line scanning across the fiber cell walls, axial parenchyma and vessel wall was carried out (Figure $3 \mathrm{C}$ with marked line). The evaluation of this line scan reveals the high UV absorbance of impregnated phenolic extractives into the cell lumen, pit canals and adjacent cell walls, visible as clear peaks with numerical values of 0,80 to overflow, illustrated by the yellow, grey and black pixels. Similar findings were achieved earlier by Koch et al. (2006) for merbau (Intsia spp.) and afzelia (Afzelia spp.) and verified as an impregnation of the cell walls by phenolic extractives, synthesized by pit membrane-associated enzymes (Hillis 1996, 1998).

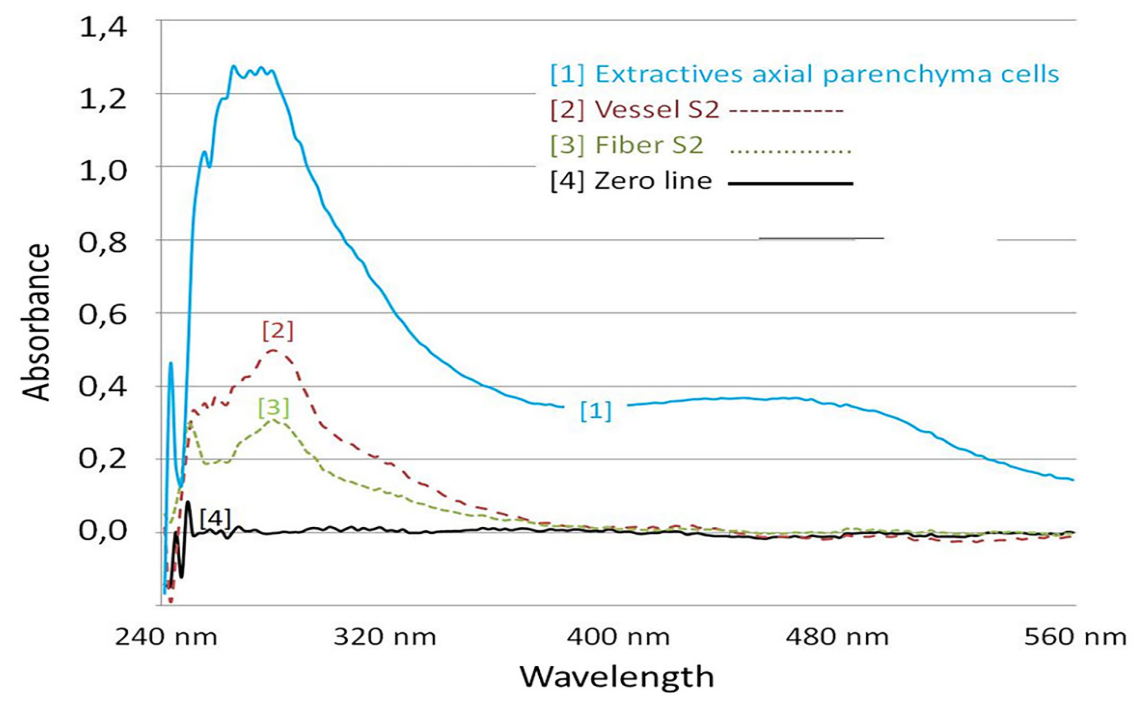

Figure 4: Representative UV absorbance spectra of individual cell walls S2 of fiber [2] and vessel [3] and deposited extractives in axial parenchyma in heartwood tissue of Cedrelinga cateniformis.

The lignification of individual cell wall layers and deposition of extractives was further studied by evaluation of the UV absorbance spectra in a wavelength range of $240 \mathrm{~nm}$ to $560 \mathrm{~nm}$. In Figure 4 representative UV absorbance spectra of the S2 of a fiber and vessel as well as deposited extractives in the axial parenchyma cells are presented.

The UV spectra of the S2 show the typical absorbance behaviour of a hardwood lignin with a distinct maximum at $278 \mathrm{~nm}$ and a local minimum at about $250 \mathrm{~nm}$. The maximum absorbance at $278 \mathrm{~nm}$ usually indicates the presence of the strongly absorbing guaiacyl/syringyl lignins (Fergus and Goring 1970).

The phenolic extractives in the axial parenchyma of Cedrelinga cateniformis heartwood reveal much higher absorbance values $(0,90$ and 1,30$)$ than cell wall associated lignins $(0,30$ and 0,50$)$. Furthermore, their absorbance maxima show a bathochromic shift to a wavelength of $286 \mathrm{~nm}$ to $288 \mathrm{~nm}$ and distinct shoulder at a wavelength range of 420 to $480 \mathrm{~nm}$ (Figure 4). This spectral behaviour can be explained by the formation of high condensed phenolic extractives with conjugated double bonds. The higher degree of conjugation stabilizes $\pi-\pi^{*}$ transitions, resulting in absorbance bands shifted to higher wavelengths (Goldschmid 1971) which can be detected by UV microspectrophotometry. However, the technique does not allow a precise chemical identification of the condensed phenolic extractives. In general, the topochemical analyses clearly evidence the synthesis and deposition of phenolic extractives during obligatory heartwood formation contributing to the high natural durability of Cedrelinga cateniformis. 


\section{Properties}

\section{Natural durability - Resistance against basidiomycetes}

The results of biological tests against basidiomycetes are shown in Table 3 and Figure 5.

The tests are considered valid as the criterion regarding the required mass of the reference material was fulfilled according the used standards; mass loss caused by C. puteana was nearly $30 \%$ and for the other fungi at least $20 \%$ (Figure 5).

Table 3: Moisture content of the specimens after 16 weeks of exposure.

\begin{tabular}{|c|c|c|c|c|c|}
\hline \multirow{2}{*}{ Fungus } & Material & \multicolumn{4}{|c|}{ Moisture content at the end of the test (\%) } \\
\cline { 3 - 6 } & $\mathbf{m i n}$ & Mean & $\mathbf{m a x}$ & $\begin{array}{c}\text { Standard } \\
\text { deviation (\%) }\end{array}$ \\
\hline \multirow{2}{*}{ C. puteana } & P. sylvestris & 48 & 56 & 60 & 4,3 \\
\cline { 2 - 6 } & Tornillo & 28 & 34 & 43 & 3,2 \\
\hline \multirow{2}{*}{ C. versicolor } & F. sylvatica & 38 & 43 & 48 & 3,1 \\
\cline { 2 - 6 } & Tornillo & 29 & 36 & 54 & 4,7 \\
\hline \multirow{2}{*}{ G. trabeum } & P. sylvestris & 49 & 54 & 57 & 2,7 \\
\cline { 2 - 6 } & Tornillo & 29 & 31 & 35 & 1,4 \\
\hline \multirow{2}{*}{ S. lacrymans } & P. sylvestris & 45 & 48 & 52 & 2,6 \\
\cline { 2 - 6 } & Tornillo & 16 & 36 & 47 & 4,4 \\
\hline
\end{tabular}

Table 3 shows that the mean moisture content of the specimens is near or higher than fiber saturation. Based on this moisture content a fungal attack should be possible. Independent of the fungus the median mass loss is clearly less than $5 \%$ resulting in a durability class 1 against basidiomycetes.

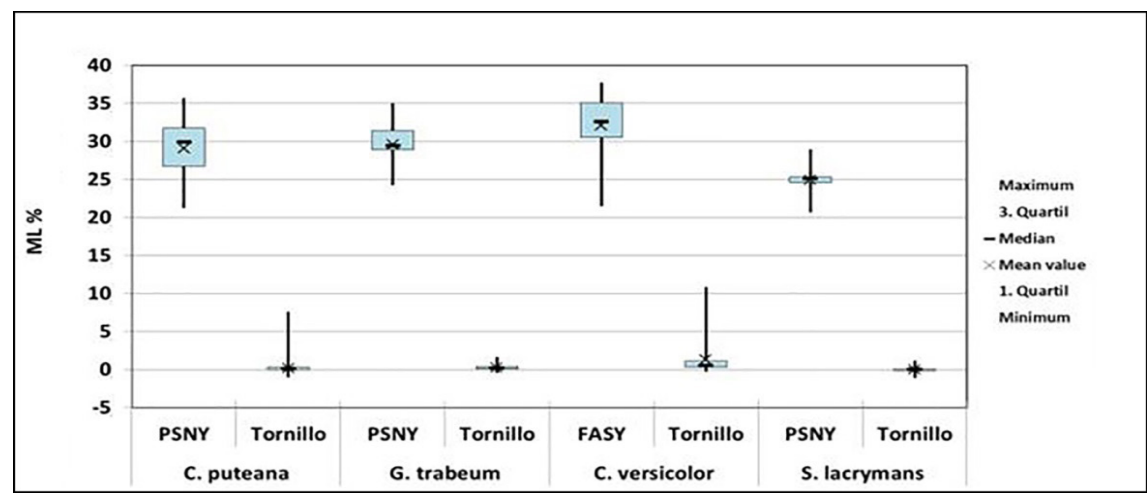

Figure 5: Mass loss of Tornillo, Pinus sylvestris (PNSY) and Fagus sylvatica (FASY) caused by the various fungi after 16 weeks of exposure.

An identical result is obtained assessing the $\mathrm{x}$-value. The $\mathrm{x}$-value is calculated using the highest mass loss caused by a fungus (worst case scenario). In the case of Tornillo the highest mean mass loss was determined for Coriolus versicolor with $1,3 \%$. If this value $(1,3 \%)$ is divided by the mean mass loss of beech $(32,0 \%)$, the $\mathrm{x}$-value is 0,04 . Since 0,04 is less than 0,15 , the durability class corresponds to class 1 (Table 1 ).

The derived durability class based on tests with basidiomycetes cannot be transferred 1:1 to in ground contact situations because it is known that biological pressure is often much more severe (presence of soil inhabiting organisms) compared to above ground situations (presence of basidiomycetes) (Meyer et al. 2014, Jacobs et al. 2019). This difference in natural durability depending on exposure type is also reflected in the actual EN 350 (2016) where for a given wood species either the durability class with ground contact or against fungi (basidiomycetes) or both durability classes are mentioned. In the US for example the AWPA standard 
(2017) E18-15 is used for the durability classification against fungi (basidiomycetes).

The results of the comprehensively tested physical, mechanical and biological properties of Cedrelinga cateniformis are presented in Table 4. The results are compared with literature data of wood species currently used for window manufacturing and outdoor applications, such as true mahogany (Swietenia macrophylla) and relevant trade groups of red meranti (Shorea subg. Rubroshorea).

The physical, mechanical and biological properties of Cedrelinga cateniformis (Table 4) are comparable to species for which a well-established market already exists.

Table 4: Results of the Assessment of physical, mechanical and biological properties.

\begin{tabular}{|c|c|c|c|c|}
\hline $\begin{array}{c}\text { Physical } \\
\text { Properties }\end{array}$ & $\begin{array}{c}\text { Tornillo } \\
\text { (Cedrelinga } \\
\text { cateniformis) }\end{array}$ & $\begin{array}{l}\text { Mahogany } \\
\text { (Swietenia } \\
\text { macrophylla) }\end{array}$ & $\begin{array}{c}\text { Light Red } \\
\text { Meranti } \\
\text { (Shorea subg. } \\
\text { Rubroshorea) }\end{array}$ & $\begin{array}{c}\text { Dark Red } \\
\text { Meranti } \\
\text { (Shorea subg. } \\
\text { Rubroshorea) }\end{array}$ \\
\hline $\begin{array}{l}\text { Density kiln dried }{ }^{* 2^{*} 3} \\
\left(12-15 \% \mathrm{mc}-\mathrm{kg} / \mathrm{m}^{3}\right)\end{array}$ & $420 \quad 520 \quad 620^{* 1}$ & $450 \ldots 600$ & $380 \ldots 580$ & $580 \ldots 680$ \\
\hline \multicolumn{5}{|l|}{$\begin{array}{c}\text { Shrinkage (\%) } \\
\left(\mathrm{mc}_{\max }-12-15 \% \mathrm{mc}\right)\end{array}$} \\
\hline Radial & $1,0 \quad 1,3 \quad 1,6^{* 1}$ & 2,6 & 3,6 & 4,0 \\
\hline tangential & $3,7 \quad 3,4 \quad 4,3^{* 1}$ & 3,7 & 7,1 & 7,6 \\
\hline \multicolumn{5}{|l|}{$\begin{array}{c}\text { Differential swelling }{ }^{* 3} \\
(\% / \%)\end{array}$} \\
\hline Radial & $\begin{array}{llll}0,13 & 0,15 & 0,17^{* 1}\end{array}$ & $0,11 \ldots 0,15$ & $0,11 \ldots 0,18$ & $0,14 \ldots 0,18$ \\
\hline Tangential & $\begin{array}{lll}0,25 & 0,28 & 0,32^{* 1}\end{array}$ & $0,17 \ldots 0,23$ & $0,25 \ldots 0,30$ & $0,29 \ldots 0,34$ \\
\hline \multicolumn{5}{|l|}{$\begin{array}{l}\text { Mechanical properties } \\
\text { (at } 12-15 \% \mathrm{mc} \text { ) }\end{array}$} \\
\hline $\begin{array}{l}\text { Modulus of Elasticity }{ }^{* 2} \\
\text { (MOE) }\left(\mathrm{N} / \mathrm{mm}^{2}\right)\end{array}$ & 10900 & 10790 & 13620 & 13020 \\
\hline $\begin{array}{l}\text { Crushing strength }{ }^{* 2} \\
\left(\mathrm{~N} / \mathrm{mm}^{2}\right)\end{array}$ & 38 & 54 & 42 & 52 \\
\hline $\begin{array}{l}\text { Static bending Strength } \\
{ }^{*_{2}}\left(\mathrm{~N} / \mathrm{mm}^{2}\right)\end{array}$ & 70 & 85 & 86 & 92 \\
\hline \multicolumn{5}{|l|}{$\begin{array}{c}\text { Biological } \\
\text { properties } \\
\text { (Basidiomycetes) }\end{array}$} \\
\hline Natural Durability ${ }^{* 2}$ & Very durable ${ }^{* 1}$ & durable & $\begin{array}{l}\text { Moderately to } \\
\text { poorly durable }\end{array}$ & $\begin{array}{c}\text { Durable to poorly } \\
\text { durable }\end{array}$ \\
\hline
\end{tabular}

${ }^{* 1}$ Data in bold are evaluated in the context of the above citied studies (species investigated originated from Peru) Data in italics are documented in the references (CIRAD-FORÊT $2017^{* 2}$, Sell 1997*3).

With regard to durability, Cedrelinga cateniformis significantly outperforms the other timber species. In summary, the wood of Cedrelinga cateniformis can be rated as ideally suited for window, door, and outdoor applications.

\section{CONCLUSIONS}

The present work provides basic results for the characterization of the wood properties of Cedrelinga cateniformis Ducke (Tornillo, Cedrorana) as a substitute for timbers used for window manufacturing and outdoor applications using a variety of state-of-the-art methods. The results reveal that the methods chosen are ideally suited to characterize the wood features. In summary, the wood Cedrelinga cateniformis wood can be rated as ideal suited for the given area of outdoor applications. As a follow-up, further investigations on comparable tropical "lesser known species" with additional focus on mechanical properties and natural durability should be conducted. These results are a precious means for understanding the wood properties of the timbers investigated under the aspect of their utilisation and to increase the added value of these valuable timbers. 


\section{ACKNOWLEDGEMENTS}

The authors thank Tanja Potsch for assistance with the ultracut-microtome and FESEM, Daniela Paul for assistance in UMSP application, Marie T. Lenz for assistance with the durability test performance as well as assistance in evaluating the related results, Dörte Bielenberg and Bettina Steffen for performance in the assessment of Physical Properties as well as assistance in evaluating the related results.

\section{REFERENCES}

American Wood Protection Association. AWPA. 2017. Standard field test for evaluation of wood preservatives to be used above ground (UC3B): Ground proximity decay test. Standard E18-15. AWPA Book of Standards: Birmingham, Alabama

Barefoot, A.C.; Traywick, J.D. 1971. Mechanical and related properties of Tornillo (Cedrelinga catenaformis). Wood Science 3(4): 245-253.

Blohm, J.H.; Melcher, E.; Lenz, M.T.; Koch, G.; Schmitt, U. 2014. Natural durability of Douglas fir (Pseudotsuga menziesii (Mirb.) Franco) heartwood grown in southern Germany. Wood Mater Sci Eng 9(3): 186-191. https://doi.org/10.1080/17480272.2014.903296.

Brown, N.; Jennings, S.; Clements, T. 2003. The ecology, silviculture and biogeography of mahogany (Swietenia macrophylla): a critical review of the evidence. Perspect Plant Ecol Evol Syst 6(1): 37-49.

European Committee for Standardization. CEN. 2005. Durability of wood and wood-based Products - Determination of the natural durability of solid wood against wood-destroying fungi, test methods - Part 1: Basidiomycetes. CEN/TS 15083-1. 2005.

European Committee for Standardization. CEN. 2016. Durability of wood and wood-based products Testing and classification of the durability to biological agents of wood and wood-based materials. CEN. EN 350. 2016.

European Committee for Standardization. CEN. 1994. Durability of wood and wood-based products - Natural durability of solid wood - Part 1: Guide to the principles of testing and classification of the natural durability of wood. CEN. EN 350-1. 1994.

CIRAD-FORÊT. 2017. Tropix 7, Fiches techniques Version 7.5.1. $<$ https://tropix.cirad.fr/en/technical-sheets-available>.

Deutsches Institut für Normung. DIN. 1976. Prüfung von Holz - Bestimmung der Rohdichte. DIN 52182. 1976. (Testing of wood - determination of density). Beuth Verlag: Berlin.

Deutsches Institut für Normung. DIN. 1979. Prüfung von Holz - Bestimmung der Quellung und Schwindung. DIN 52184. 1979-05. (Testing of wood - determination of swelling and shrinkage). Beuth Verlag: Berlin.

Dünisch, O.; Richter, H.G.; Koch, G. 2010. Wood properties of juvenile and mature heartwood in Robinia pseudoacacia L. Wood Sci Technol 64(3): 301-313. https://doi.org/10.1007/s00226-009-0275-0.

Fergus, B.J.; Goring, D.A.I. 1970. The distribution of lignin in birch wood as determined by ultraviolet microscopy. Holzforschung 24(4): 118-124. https://doi.org/10.1515/hfsg.1970.24.4.118.

Foerster, R.; Albrecht, H.; Belisle, M.; Caballero, A.; Galetti, H.; Lacayo, O. ; Ortiz, S. 2003. Forest communities and the marketing of lesser-known tropical hardwoods in Mesoamerica. ISBN 968-7864-47-8 Ciudad de México, Mexico.

Franklin, GL. 1945. Preparation of thin sections of synthetic resins and wood-resin composites, and a new maceration method for wood. Nature 155(1945): 51-53. https://doi.org/10.1038/155051a0.

Goldschmid, O. 1971. Ultraviolet spectra. In Lignins, Occurrence, Formation, Structure and Reactions. Wiley Interscience, New York. ISBN: 0471754226. 
Gullison, R.E.; Panfil, S.N.; Strouse, J.J.; Hubbell, S.P. 1992. Regeneración natural de la mara (Swietenia macrophylla) en el bosque chimanes, Bolivia. Ecología en Bolivia 19: 43-56.

Gullison, R.E.; Panfil, S.N.; Strouse, J.J.; Hubbell, S.P. 1996. Ecology and management of mahogany (Swietenia macrophylla King) in the Chimanes Forest, Beni, Bolivia. Bot J Linn Soc 122(1): 9-34.

Grogan, J.; Jennings, S.B.; Landis, R.M.; Schulze, M.; Baima, A.M.; Lopez, J.D.C.A.; Norghauer, J.M.; Oliveira, L.R.; Pantoja, F.; Pinto, D.; Silva, J.N.M.; Vidal, E.; Zimmerman, B.L. 2008. What loggers leave behind: Impacts on big-leaf mahogany (Swietenia macrophylla) commercial populations and potential for post-logging recovery in the Brazilian Amazon. For Ecol Manag 255(1): 269-281. https://doi. org/10.1016/j.foreco.2007.09.048.

Grossheim, C. 2011. Forest Concessions in Peru. In Silviculture in the Tropics (pp. 53-60). Springer, Berlin, Germany.

Günter, S.; Weber, M.; Stimm, B.; Mosandl, R. 2011. Silviculture in the Tropics, Tropical Forestry 8 , Springer-Verlag Berlin Heidelberg, Germany.

Hall, J. 2008. Seed and seedling survival of African mahogany (Entandrophragma spp.) in the Central African Republic: implications for forest management. For Ecol Manag 255(2): 292-299. https://doi. org/10.1016/j.foreco.2007.09.050.

Hall, J. 2011. Natural Forest Silviculture for Central African Meliaceae. In Silviculture in the Tropics. Springer: Berlin, Germany, 219-225.

Hapla, F.; Saborowski, J. 1987. Stichprobenplanung für holzanatomische Untersuchungen. Holz RohWerkst 45(4): 141-144. https://doi.org/10.1007/BF02627564.

Haupt, M.; Leithoff, H.; Meier, D.; Puls, J.; Richter, H.G.; Faix, O. 2003. Heartwood extractives and natural durability of plantation-grown teakwood (Tectona grandis L.) - a case study. Holz Roh- Werkst 61(6): 473-474. https://doi.org/10.1007/s00107-003-0428-z.

Helmling, S.; Olbrich, A.; Heinz, I.; Koch, G. 2018. Atlas of vessel elements: identification of Asian timbers. IAWA J 39(3): 249-352.

Hillis, W.E. 1996. Formation of robinetin crystals in vessels of Intsia species. IAWA J 17(4): 405-419.

Hillis, W.E. 1998. Deposits in heartshakes in wood - Part 1. Different types. Wood Sci Technol 32(2): 129137. https://doi.org/10.1007/BF00702593.

Inada, T.; Widiyatno; Hardiwitono, S.; Purnomo, S.; Putra, I.B.W.; Kitajima, K.; Kanzaki, M. 2017. Dynamics of forest regeneration following logging management in a bornean lowland dipterocarp forest. $J$ Trop For Sci 29(2): 185-197.

International Organization for Standardization. ISO. 2014. Physical and mechanical properties of wood - Test methods for small clear wood specimens - Part 2: Determination of density for physical and mechanical tests. ISO 13061-2. 2014. International Organization for Standardization: Genf: Swiss.

International Organization for Standardization. ISO. 2014. Physical and mechanical properties of wood - Test methods for small clear wood specimens - Part 13: Determination of radial and tangential shrinkage. ISO/FDIS 13061-13. 2014. International Organization for Standardization: Genf, Swiss.

Jacobs, K.; Plaschkies, K.; Scheiding, W.; Weiß, B.; Melcher, E.; Conti, E.; Fojutowski, A.; Le Bayon, I. 2019. Natural durability of important European wood species against wood decay fungi. Part 2: Field tests and fungal community. Int Biodeter Biodegr 137(2019): 118-126. https://doi.org/10.1016/j.ibiod.2018.12.002.

Kleist, G.; Schmitt, U. 1999. Evidence of accessory compounds in vessel walls of Sapelli heartwood (Entandrophragma cylindricum) obtained by transmission electron microscopy. Holz Roh-Werkst 57(2): 93-95. https://doi.org/10.1007/PL00002633.

Koch, G.; Grünwald, C. 2004. Application of UV microspectrophotometry for the topochemical detec- 
tion of lignin and phenolic extractives in wood fibre cell walls. In Wood fibre cell walls: method to study their formation, structure and properties. Schmitt, U (Ed.). pp 119-130. COST Action E20: Brussels, Belgium.

Koch, G.; Richter, H.G.; Schmitt, U. 2006. Topochemical investigation on phenolic deposits in the vessels of afzelia (Afzelia spp.) and merbau (Intsia spp.) heartwood. Holzforschung 60(6): 583-588. https://doi. org/10.1515/HF.2006.099.

Koch, G.; Kleist, G. 2001. Application of scanning UV microspectrophotometry to localise lignins and phenolic extractives in plant cell walls. Holzforschung 55(6): 563-567. https://doi.org/10.1515/HF.2001.091.

Koch, G. 2016. Rotes Meranti für den konstruktiven Fensterbau. In: Rotes Meranti aus Malaysia für den Einsatz im Fensterbau. Kuala Lumpur: Malaysian Timber Council, 10-11.

Meyer, L.; Brischke, C.; Melcher. E.; Brandt, K.; Lenz, M.T.; Soetbeer, A. 2014. Durability of English oak (Quercus robur L.) - Comparison of decay progress and resistance under various laboratory and field conditions. Int Biodeter Biodegr 86: 79-85. https://doi.org/10.1016/j.ibiod.2013.06.025.

Putzel, L.; Peters, C.M.; Romo, M. 2011. Post-logging regeneration and recruitment of shihuahuaco (Dipteryx spp.) in Peruvian Amazonia: Implications for management. For Ecol Manage 261(6): 1099-1105. https://doi.org/10.1016/j.foreco.2010.12.036.

Purwaningsih; Kintamani, E. 2018. The Diversity of Shorea spp. (Meranti) at Some Habitats. Indonesia IOP Conf. Series: Earth and Environmental Science 197(1): 012034.

Rodríguez Anda, R.; Koch, G.; Richter, H.G.; Fuentes Talavera, F.J.; Silva Guzman, J.A.; Satyanarayana, K.G. 2019. Formation of heartwood, chemical composition of extractives and natural durability of plantation grown teak wood from Mexico. Holzforschung 73(6): 547-557. https://doi.org/10.1515/hf-20180109 .

Scholz, G.; Liebner, F.; Koch, G.; Bues; C.T.; Günther, B.; Bäucker, E. 2007. Chemical, anatomical and technological properties of Snakewood (Brosimum guianense (Aubl.) Huber). Wood Sci Technol 41(8): 673686. https://doi.org/10.1007/s00226-007-0149-2. $223-6$

Sell, J. 1997. Eigenschaften und Kenngrössen von Holzarten. Dietikon : Baufachverlag. ISBN: 3-85565-

Silva-Guzmán, J.A. 2012. Proyecto ITTO PD 385/05: Industrialización, Comercialización y Manejo Sostenible de Diez Especies Nativas Mexicanas. Capítulo 3: Caracterización tecnológica de las especies de madera. Informe final Universidad de Guadalajara, Departamento de Madera, Celulosa y Papel, Centro Universitario de Ciencias Exactas e Ingenierías. Guadalajara, Jalisco, Mexico.

Sist, P.; Nolan, T.; Bertault, J.G.; Dykstra D. 1998. Harvesting intensity versus sustainability in Indonesia. For Ecol Manage 108(3): 251-260. https://doi.org/10.1016/S0378-1127(98)00228-X.

Sist, P.; Nguyen-Thé, N. 2002. Logging damage and the subsequent dynamics of a dipterocarp forest in East Kalimantan (1990-1996). For Ecol Manag 165(1-3): 85-103. https://doi.org/10.1016/S03781127(01)00649-1.

Sist, P.; Fimbel, R.; Nasi, R.; Sheil, D.; Chevallier, M.H. 2003. Towards sustainable management of mixed dipterocarp forests of South East Asia: moving beyond minimum diameter cutting limits. Environ Conserv 30(4): 364-374.

Spurr, A.R. 1969. A low-viscosity epoxy resin embedding medium for electron microscopy. $J$ Ultrastruct Res 26(1): 31-43. https://doi.org/10.1016/S0022-5320(69)90033-1.

Verwer, C.; Pena-Claros, M.; Van Der Staak, D.; Ohlson-Kiehn, K.; Sterck, F.J. 2008. Silviculture enhances the recovery of overexploited mahogany Swietenia macrophylla. J Appl Ecol 45(6): 1770-1779. https:// doi.org/10.1111/j.1365-2664.2008.01564.x.

Wheeler, E.A.; Baas, P.; Gasson, P.E. 1989. List of microscopic features for hardwood identification. IAWA Bull 10(3): 219-332. 